\title{
USE OF INDICATORS OF BIOCHEMICAL COMPOSITION OF SEEDS FOR BREEDING FOR HETEROSIS WINTER OILSEED RAPE BASED CYTOPLASMIC MALE STERILITY
}

\section{ВИКОРИСТАННЯ ПОКАЗНИКІВ БІОХІМІЧНОГО СКЛАДУ НАСІННЯ ПРИ СЕЛЕКЦІЇ НА ГЕТЕРОЗИС РІПАКУ ОЗИМОГО НА ОСНОВІ ЦИТОПЛАЗМАТИЧНОЇ ЧОЛОВІЧОЇ СТЕРИЛЬНОСТІ}

\section{Sergey Vyshnevsky ${ }^{1}$}

DOI: https://doi.org/10.30525/978-9934-26-077-3-26

Abstract. The paper presents the results of research (2014-2017) on the creation of source material for the selection of hybrids of winter oilseed rape on the basis of cytoplasmic male sterility. The source material was varieties, hybrids, lines of individual selection of the Institute of Feed Research and Agriculture of Podillya NAAS, collection samples of domestic and foreign selection. We used 44 genotypes of winter oilseed rape in 2014-16 as parents for pollination with a form with cytoplasmic male sterility. Material for breeding was taken taking into account many years of processing according to seed productivity, indicators of biochemical composition, winter resistance, oleaginousness, length of growing season, lesion of pathogens of disease and damage to pests. To accelerate the selection process for the creation of competitive domestic varieties and hybrids of winter oilseed rape, studies were conducted on the biochemical parameters of seeds of $\mathrm{F}_{1}$ hybrids obtained on the basis of cytoplasmic male sterility. By indicators of the content of erucic acid, glucosinolates from 25 combinations of 2016, seven combinations are allocated, in which the biochemical composition of the seeds correspond to such requirements; Oil - erucic acid is absent, or its traces are contained, and the content of glucosinolates does not exceed $25 \mu \mathrm{mol} / \mathrm{g}$. In 2017, in studies on the manifestation of heterosis and the creation of highly heterosis hybrids using CMS on their basis, 19 new hybrids and 7 best ones of 2016 were used. In terms of oil quality and

\footnotetext{
${ }^{1}$ Scientific Associate, Institute of Feed Research and Agriculture of Podillya NAAS, Ukraine

(C) Sergey Vyshnevsky
} 
yield in 2017 with 26 numbers have highlighted 15, 7 of them are of 2016. According to the results of a two-year trial, we have the following results: 2016 , the total average crop capacity of the 7 best hybrids was $7.41 \mathrm{t} / \mathrm{ha}$, which was $2.59 \mathrm{t} / \mathrm{ha}$ higher than the standard; 2017, these combinations showed a total average crop capacity of $6.58 \mathrm{t} / \mathrm{ha}$, which was $1.8 \mathrm{t} / \mathrm{ha}$ higher than the standard. The manifestation of heterosis in winter oilseed rape hybrids on average for two years was observed at $46 \%$. The expediency of selection work is determined, to create the source material of commercial hybrids of winter oilseed rape, which includes early detection, even at the stage of first-generation hybrids, promising two-zero lines of restorers and fixers of cytoplasmic male sterility. The study gives the chance in the further exclusion from the selection program of works on improvement of biochemical indicators of the received initial material.

\section{1. Ветуп}

Олія ріпаку висококалорійна, має велику енергетичну віддачу. При згорянні грама ріпакової олії виділяється 9.5 тис. калорій, у той час, як при згорянні цієї кількості білка - 5.5 тис, вуглеводів 4 - тис, сала 9.5 тис, вершкового масла - 7.8 тис. калорій. Високобілковий шрот використовується для годівлі тварин. Якість олії визначається відсутністю в ній небажаного компонента - ерукової кислоти та співвідношенням основних жирних кислот, які і визначають харчові чи технічні властивості олії.

Ріпак - надзвичайно цінна кормова культура. При його переробці 3 кожних 100 кг насіння одержують до 41 кг олії та 57 кг макухи. Гектар цієї культури (при врожайності 30 ц/га) забезпечує вихід 1.0-1.3 т олії i 1.6-1.8 т шроту, який містить близько 40\% добре збалансованого за амінокислотним складом білка. У 100 кг ріпакового шроту міститься в середньому 90 кормових одиниць, коефіцієнт перетравності органічних речовин сягає $71 \%$, в той час як соняшникового - 56\%. Ріпаковий шрот переважає соняшниковий і за вмістом незамінних амінокислот: лізину - на 33\%, цистину - у 2.1 рази.

Раніше використання ріпакової олії в харчуванні людини та ріпакової макухи (шроту) в годівлі сільськогосподарських тварин ускладнювалося наявністю в насінні ріпаку шкідливих речовин - ерукової кислоти та глюкозинолатів, характерних для більшості диких форм 
рослин з родини хрестоцвітих. Останні $є$ небажаною шкідливою речовиною, яка обмежує використання шроту для годівлі тварин $[1 ; 2 ; 3]$.

На даний час понад 90\% площ посівів ріпаку на насіння зайнято сортами олійного напряму використання (двонульового або „00”-типу), у яких в олії ерукова кислота відсутня, або містяться ㄲï сліди, а вміст глюкозинолатів не перевищує 25 мкмоль/г. Решта посівів припадає на сорти технічного напряму використання (плюс-нуль або „,+0”-типу), у яких вміст ерукової кислоти підвищений до 45\%, а глюкозинолатів, навпаки знижений до 25 мкмоль/г.

Селекційний процес з одночасного підвищення насіннєвої продуктивності та покращення біохімічної якості генотипів має пройти більш довгий та важкий шлях, ніж селекція тільки на підвищену врожайність.

Таким чином покращення біохімічного складу олії ріпаку озимого, зокрема зниження в ній вмісту ерукової кислоти, можливе на даний час поки що тільки селекційним шляхом [4].

Для проведення подальшої ефективної селекційної роботи з покращення біохімічного складу та співвідношення основних жирних кислот ріпаку озимого важливо широко використовувати попередньо вивчений вихідний матеріал генетичної колекції, який містить значну різноманітність біохімічних показників та ознак.

Аналіз останніх досліджень $і$ публікацій. Ріпак озимий вирощується для отримання двох основних продуктів - олії і шроту. Ріпак з показниками 40-45\% олії є одним з цінних і найважливіших олійних культур [5; 6; 7].

Типовим прикладом гетерозису серед рослин $є$ ріпак який в дикому стані не виявлено, але за походженням він є природний амфідиплоїд. Його гібридне походження $є$ результат спонтанного схрещування капусти та суріпиці. Капуста Brassica olearacea (2n-18, геном CC) х суріпиця Brassica campestris (2n-20 геном AA) - ріпак Brassica napus 3 генетичною формулою ААСС (2n-38) [8; 9; 10; 11; 12].

Практичне використання гетерозису у великій кількості культур на мільйонах гектарів по всьому світу є показником успішності. Ступінь гетерозису в ріпаку був проаналізований в ряді досліджень. Для гібридів озимого ріпаку середній прояв гетерозису 50\%, в межах від 20 до $80 \%$. $Є$ повідомлення про прояв гетерозису у озимого ріпаку $120 \%$ для врожаю насіння [13]. Рівень гетерозису, що виявлений при дослідженні може виправдати розробку комерційних $\mathrm{F}_{1}$ гібридів $[2 ; 14 ; 15 ; 16]$. 
Використання (ЦЧС) в гетерозисній селекції мають проблему з біохімічними показниками насіння, для цього потрібно проводити селекційну програму з покращення біохімічних показників $[17 ; 18]$.

В даний час прогрес при створенні нових гібридів ріпаку озимого базується на виведенні і впровадженні гетерозисних гібридів, це обумовлено рядом суттєвих біологічних і технологічних переваг гібридів перед сортами-популяціями - можливо стало за використання ефекту цитоплазматичної чоловічої стерильності (ЦЧС).

При створенні гібридів ріпаку озимого в загальному використовується 3 типи цитоплазматичної чоловічої стерильності Ogura, Napus, Polima [18].

Мета роботи: створення вихідного матеріалу для селекції гібридів ріпаку озимого на основі цитоплазматичної чоловічої стерильності.

\section{2. Матеріали та методи дослідження}

Вихідним матеріалом слугували сорти, гібриди, лінії індивідуального добору Інституту кормів та сільського господарства Поділля НААН, колекційні зразки вітчизняної та зарубіжної селекції. Було використано 44 генотипів ріпаку озимого, який ми використовували у 2014-16 роках в якості батьків для запилення із формою з цитоплазматичною чоловічою стерильністю.

Матеріал для схрещування добирався 3 урахуванням багаторічного опрацювання в попередні роки, за насіннєвою продуктивністю, показників біохімічного складу, зимостійкістю, олійністю, довжиною вегетаційного періоду, ураженням збудниками хвороби і пошкодженням шкідниками.

Дослідження проводилися в селекційній сівозміні, грунти за агрономічною характеристикою переважно сірі опідзолені, шар грунту 0-30 см, гумусу $2.0 \%$, гідролізованого азоту 9.6 мг/100 гр, рухомого фосфору 13.0 мг/100 гр, обмінного калію 11.5 мг/100 гр, гідролітична кислотність $\mathrm{Hr} 3.5$ мк.екв./100 гр грунту, сума ввібраних основ 13 мк.екв./100 гр, $\mathrm{pH}-5.5$.

За агрокліматичними показниками територія дослідних полів Інституту кормів та сільського господарства Поділля НААН відноситься до зони з помірно-континентальним кліматом. Найближча метеостанція розташована в м. Вінниця. Метеорологічні місячні дані показники середньомісячної температури та кількості опадів показані в таблиці 1 . 
Таблиця 1

Середньорічна температура повітря та сума атмосферних опадів в роки проведення досліджень

\begin{tabular}{|c|c|c|c|c|c|c|c|c|c|c|c|c|}
\hline \multirow{2}{*}{ Період } & \multicolumn{12}{|c|}{ Місяці } \\
\hline & VIII & IX & $\mathbf{X}$ & $\mathbf{X I}$ & XII & $\mathbf{I}$ & II & III & IV & $\mathbf{V}$ & VI & VII \\
\hline \multicolumn{13}{|c|}{ Сума опадів, мм } \\
\hline 2014-2015 pp. & 47 & 32 & 30 & 43 & 20 & 32 & 19 & 42 & 37 & 34 & 36 & 15 \\
\hline 2015-2016 pp. & 4 & 35 & 46 & 54 & 14 & 35 & 50 & 19 & 30 & 54 & 52 & 43 \\
\hline 2016-2017 pp. & 31 & 3 & 63 & 52 & 36 & 28 & 39 & 63 & 40 & 28 & 20 & 50 \\
\hline Ср.баг. & 68.0 & 46.0 & 38.0 & 42.0 & 44.0 & 40.0 & 38.0 & 35.0 & 49.0 & 63.0 & 87.0 & 92.0 \\
\hline \multicolumn{13}{|c|}{ Сума температур, ${ }^{\circ} \mathrm{C}$} \\
\hline Період & VIII & IX & $\mathbf{X}$ & $\mathbf{X I}$ & XII & I & II & III & IV & $\mathbf{V}$ & VI & VII \\
\hline $2014-2015 \mathrm{pp}$. & 20.0 & 14.5 & 7.1 & 1.4 & -2.1 & -1.1 & -1.3 & 4.0 & 8.5 & 15.3 & 19.3 & 21.2 \\
\hline 2015-2016 pp. & 21.2 & 17.0 & 7.1 & 4.2 & 1.7 & -5.2 & 2.2 & 4.0 & 11.8 & 14.2 & 19.4 & 20.8 \\
\hline 2016-2017 pp. & 19.9 & 15.9 & 5.8 & 1.1 & -2.1 & -5.8 & -3.1 & 5.7 & 9.2 & 13.9 & 19.1 & 19.9 \\
\hline Ср.баг. & 17.7 & 13.4 & 7.7 & 1.9 & -2.5 & -5.8 & -4.3 & 0.2 & 8.0 & 14.1 & \begin{tabular}{|l|}
17.1 \\
\end{tabular} & 18.3 \\
\hline
\end{tabular}

Під час вегетації проведені фенологічні спостереження за ростом і розвитком рослин, відмічені повні сходи, фази утворення листків, розетки, бутонізації, стеблування, утворення суцвіть, початку і кінця цвітіння.

Урожай обліковувався методом суцільного обмолоту, вміст олії в насінні визначався на комп'ютерному аналізаторі і методом С. В. Рушковського, глюкозинолати методом паперового глюкотеста, ерукова кислота - методом помутніння нагрітого до $70^{\circ} \mathrm{C}$ розчину в етанолі (1:80) олії $\left(0,1\right.$ мл) при різкому іiї охолодженні $\left(+21^{\circ} \mathrm{C}\right)$.

\section{3. Результати дослідження та їх обговорення}

32015 року робота по гетерозисній селекції проводилася з використанням форми озимого ріпаку з чоловічою цитоплазматичною стерильністю. Гібриди ріпаку озимого отримані на цій основі значно перевищують сорти ріпаку за урожайністю, та якісним показникам продукції.

Прояв гетерозису може бути практично перспективним лише в тому випадку якщо він за врожайністю істотно перевищує не лише батьківський компонент $\left(H_{t}\right.$ - гіпотетичний гетерозис) але ї сорт стандарт, що є показником конкурсного гетерозису $\left(H_{\text {кон }}\right)$ які вираховуються за формулами. 
Формули визначення ступеня гетерозису.

$$
\begin{gathered}
H_{\text {кон }}=\left(F_{1}-C\right): C \cdot 100 \\
H_{t}=\left(F_{1}-P\right): P \cdot 100
\end{gathered}
$$

де $F_{1}$ - значення ознаки у гібрида;

$C-$ значення ознаки у сорту стандарт;

$P$ - значення ознаки у батьківської форми

Ступінь прояву гетерозису за ознакою урожайність насіння у гібридів першого покоління 2016 р. на основі (ЦЧС) у порівняні із стандартом, і батьківською формою представлені в таблиці 2.

Ступінь прояву гетерозису за ознакою урожай насіння в 2017 р. гібридів $\mathrm{F}_{1}$ на основі (ЦЧС) у порівняні із стандартом, $\mathrm{i}$ батьківською формою представлені в таблиці 3.

Головним критерієм оцінки гібридів першого покоління в нашому досліді був показник біохімічного складу насіння, щоб прискорити селекційну роботу і виключити необхідність проводження програми 3 покращення біохімічного складу. За показниками вмісту ерукової кислоти, глюкозинолатів з 25 комбінацій 2016 році виділилися комбінації, в яких показники біохімічного складу насіння відповідали таким вимогам - олії ерукова кислота відсутня, або містяться її сліди, а вміст глюкозинолатів не перевищує 25 мкмоль/г: 39 (ЦЧС) $\times$

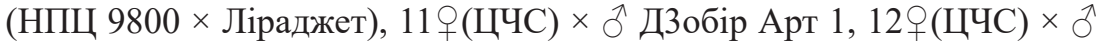
$($ Вотан $\times$ Livins), $13 q($ ЦЧС) $\times \precsim$ (Livins $\times$ Барос), $14 q($ ЦЧС) $\times \lesssim$ Добір

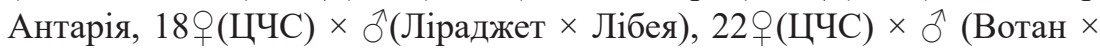
Livins). Результати якісних показників олії гібридів першого покоління 2016 року представлені в таблиці 4.

В 2017 році у дослідженнях з прояву гетерозису та створенні на ïх основі високо гетерозисних гібридів з використанням (ЦЧС) були використані 19 нових гібридів і 7 кращих минулорічних.

За якісними показниками олії і урожайністю виділилися такі номери: 26 q(ЦЧС) $\times \widehat{\jmath}($ Світоч $\times$ ЗОтаман $), 29 q(Ц Ч С) \times \widehat{\jmath}($ Форте $\times$ Чорний велетень), 30 q(ЦЧС) $\times ふ($ Ліраджет $\times$ Дар ланів), 34 q (ЦЧС $) \times$

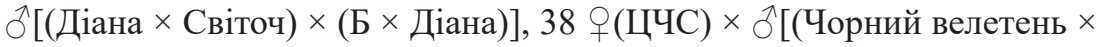
Горизонт) $\times$ Данте], 39 q (ЦЧС) $\times \widehat{\jmath}($ Нельсон $\times$ Горизонт), 41 q (ЦЧС) $\times \hat{\delta}[($ Горизонт $\times$ Л184) $\times$ Дар ланів], 42 q (ЦЧС) $\times \hat{\jmath}($ Атлант $\times$ Гори-

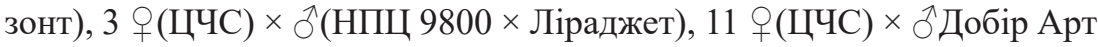


Таблиця 2

Ступінь гетерозису за ознакою урожайність у гібридів (F $)(2016$ р.)

\begin{tabular}{|c|c|c|}
\hline \multirow{2}{*}{ Гібридні комбінації } & \multicolumn{2}{|c|}{ Гетерозис } \\
\hline & $\boldsymbol{H}_{\text {кон }}$ & $\boldsymbol{H}_{t}$ \\
\hline 1. + (ЦЧС) / Љ Антарія & 46 & 47 \\
\hline 2. 甲(ЦЧС) / ठૈ (Вотан / Ліраджет) & 60 & 2 \\
\hline 3. 甲(ЦЧС) / ठૈ (НПЦ 9800 / Ліраджет) & 56 & 42 \\
\hline 4. ๆ(ЦЧС) / ठ Чорний велетень & -44 & -44 \\
\hline 5. + (ЦЧС) / つ̄ (Лібея / Ліраджет) & -54 & -60 \\
\hline 6. q(ЦЧС) / § (Добір Чорний велетень / Отаман) & -26 & -28 \\
\hline 7. ๆ(ЦЧС) / ふૈ (Данте / Дар Ланів) & 16 & 0 \\
\hline 8. ๆ(ЦЧС) / §ૈ (Ліраджет / Livins) & -36 & -35 \\
\hline 9. Ф(ЦЧС) / ふ઼ (Ліраджет / Лібея) & 16 & -26 \\
\hline 10. +(ЦЧС) / ઈે (НПЦ 9800 / Вотан) & 52 & -13 \\
\hline 11. ф(ЦЧС) / ठ Добір Арт 1 & 2 & 9 \\
\hline 12. ๆ(ЦЧС) / Љ (Вотан / Livins) & 52 & 9 \\
\hline 13. + (ЦЧС) / Љ (Livins / Барос) & 62 & 8 \\
\hline 14. ๆ(ЦЧС) / Љ Добір Антарія & 48 & 36 \\
\hline 15. +(ЦЧС) / え Добір Чорний велетень & 53 & 28 \\
\hline 16. +(ЦЧС) / ठ (Дар Ланів / Алігатор) & 81 & 100 \\
\hline 17. Ф(ЦЧС) / § Гіпаніс & 64 & 104 \\
\hline 18. + ( ЦЧС) / ठ (Ліраджет / Лібея) & 68 & 4 \\
\hline 19. ( (ЦЧС) / Љ Добір Горизонт & 8 & -32 \\
\hline 20. Я( ЦЧС) / ઈ (Ліраджет / Світоч) & -65 & -71 \\
\hline 21. +( ЦЧС) / Љ Добір (Ліраджет / Лібея) & 6 & 3 \\
\hline 22. Я( ЦЧС) / § (Вотан / Livins) & 89 & 47 \\
\hline 23. + (ЦЧС) / ठ (Лібея / Світоч) & -65 & -71 \\
\hline 24. +(ЦЧС) / § (Чорний велетень / Отаман) & -77 & -85 \\
\hline 25. Ф (ЦЧС) /ठ (Атлант / Алігатор) & -38 & -46 \\
\hline
\end{tabular}

Примітка: $H_{\text {кон }}-$ конкурсний гетерозис, $H_{t}-$ гіпотетичний гетерозис 
Таблиця 3

Ступінь гетерозису гібридів $\left(\mathrm{F}_{1}\right)(2017$ р.)

\begin{tabular}{|c|c|c|}
\hline \multirow{2}{*}{ Гібридні комбінації } & \multicolumn{2}{|c|}{ Гетерозис } \\
\hline & $\boldsymbol{H}_{\text {кон }}$ & $\boldsymbol{H}_{t}$ \\
\hline 26. (ЦЧС) / (Світоч / Отаман) & 3 & 5 \\
\hline 27. (ЦЧС) / (Дар ланів / Livins) & 31 & 0.8 \\
\hline 28. (ЦЧС) / (Форте / Барос) & -5 & 8 \\
\hline 29. (ЦЧС) / (Форте / Чорний велетень) & 7 & 36 \\
\hline 30. (ЦЧС) / (Ліраджет / Дар ланів) & 9 & 2 \\
\hline 331. (ЦЧС) / (Вікінг/Алігатор) & 22 & 3 \\
\hline 32. (ЦЧС) / (Дар ланів / Чорний велетень) & -12 & 11 \\
\hline 33. (ЦЧС) / (Лібея / Livins) & -21 & -3 \\
\hline 34. (ЦЧС) / [Діана / Світоч) / Б / Діана] & 9 & 4 \\
\hline 35. (ЦЧС) / (Вінер /Алігатор) & -24 & 9 \\
\hline 36.(ЦЧС) / [(Лібея / Світоч) / (Горизонт / л184)] & 23 & 21 \\
\hline 37. (ЦЧС) / (Вікінг/Алігатор/Вісбі) & 46 & 31 \\
\hline 38. (ЦЧС) / [(Чорний велетень / Горизонт) / Данте] & 43 & 28 \\
\hline 39. (ЦЧС) / (Нельсон / Горизонт) & 41 & 33 \\
\hline 40. (ЦЧС) / (ПР45Д03 / Горизонт) & 7 & 18 \\
\hline 41. (ЦЧС) / [(Горизонт / л184) / Дар ланів] & 19 & 11 \\
\hline 42. (ЦЧС) / (Атлант / Горизонт) & 35 & 57 \\
\hline 43. (ЦЧС) / (Форте / Світоч) & -11 & 33 \\
\hline 44. (ЦЧС) / [(Атлант / Алігатор) / ПР45Д01] & 2 & 10 \\
\hline 3. (ЦЧС) / (НПЦ 9800 / Ліраджет) & 41 & 59 \\
\hline 11. (ЦЧС) / АРТ1 & 0.8 & 4 \\
\hline 12. (ЦЧС) / (Вотан / Livins) & 28 & 19 \\
\hline 13. (ЦЧС) (Livins / Барос) & 42 & 10 \\
\hline 14. (ЦЧС) / Добір Антарія & 41 & 18 \\
\hline 18. (ЦЧС) / (Ліраджет / Лібея) & 48 & 9 \\
\hline 22. (ЦЧС) / (Вотан / Livins) & 63 & 36 \\
\hline
\end{tabular}

Примітка: $H_{\text {кон }}$ - конкурсний гетерозис, $H_{t}$ - гіпотетичний гетерозис 
Таблиця 4 Урожайність та якісні показники олії гібридів озимого ріпаку $\left(\mathrm{F}_{1}\right)$ на основі цитоплазматичної чоловічої стерильності (2016 р.)

\begin{tabular}{|c|c|c|c|c|c|}
\hline Назва & 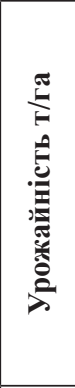 & 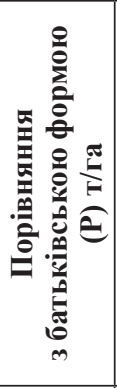 & 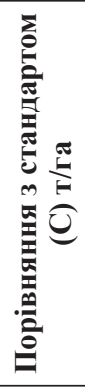 & 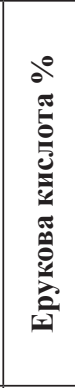 & 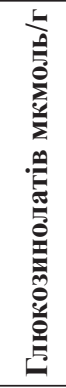 \\
\hline St Чорний велетень & 4.82 & - & - & 0.25 & 4.8 \\
\hline 1. . ( ЦЧС $) \times$ ठ Антарія & 7.02 & 2.25 & 2.20 & 1.9 & 9.6 \\
\hline 2. ㅇ ( ЦЧС $) \times \hat{~ O ̂}($ Вотан $\times$ Ліраджет $)$ & 7.71 & 0.18 & 2.89 & 2.1 & 4.8 \\
\hline 3. ○( ЦЧС) × О (НПЦ $9800 \times$ Ліраджет) & 7.52 & 2.24 & 2.70 & 0.1 & 4.2 \\
\hline 4. ㅇ (ЦЧС) × ô Чорний велетень & 2.70 & -2.15 & -2.12 & 1.6 & 1.2 \\
\hline 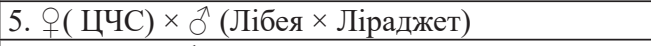 & 2.22 & -3.35 & -2.60 & 3.1 & 12.0 \\
\hline 6. + ( ЦЧС) $\times$ О人 (Добір Чорний велетень $\times$ Отаман) & 3.57 & -1.41 & -1.25 & 17.1 & 3.4 \\
\hline 7. + ( ЦЧС $) \times \hat{~}($ Данте $\times$ Дар Ланів $)$ & 5.59 & 0 & 0.77 & 1.9 & 7.2 \\
\hline 8. + ( ЦЦЧС $) \times$ ठै (Ліраджет $\times$ Livins $)$ & 3.10 & -1.68 & -1.72 & 1.3 & 2.4 \\
\hline 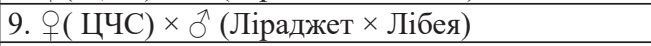 & 5.61 & -2.00 & 0.79 & 2.6 & 2.4 \\
\hline 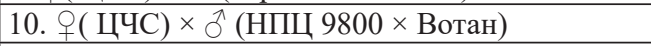 & 7.31 & -1.11 & 2.49 & 4.6 & 4.8 \\
\hline 11. + ( ЦЧС $) \times$ へ Добір Арт 1 & 4.92 & 0.42 & 0.1 & 0.0 & 4.8 \\
\hline 12. $+($ ЦЧС $) \times \bigcirc$ (Вотан $\times$ Livins $)$ & 7.33 & 0.62 & 2.51 & 0.1 & 9.6 \\
\hline 13. + (ЧЦС) $\times \hat{~}$ (Livins $\times$ Бароc) & 7.81 & 0.58 & 2.99 & 0.1 & 2.4 \\
\hline 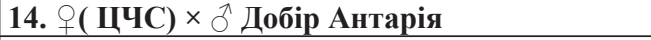 & 7.12 & 1.90 & 2.30 & 0.4 & 4.8 \\
\hline 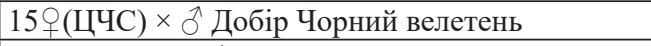 & 7.39 & 1.61 & 2.57 & 1.5 & 9.6 \\
\hline 16. + ( ЦЧС) $\times$ స (Дар Ланів $\times$ Алігатор) & 8.72 & 4.37 & 3.90 & 4.0 & 2.4 \\
\hline 17. . ( ЦЧС) $\times \hat{~ o ̂ ~ Г і п а н і с ~}$ & 7.91 & 4.04 & 3.09 & 2.0 & 9.6 \\
\hline 18. . ( ЦЧС) $\times$ О (Ліраджет $\times$ Лібея $)$ & 8.10 & $\mathbf{0 . 3 0}$ & 3.28 & 0.0 & 12.0 \\
\hline 19. ․ (ЦЧС) $\times$ ठ Добір Горизонт & 5.20 & -2.42 & 0.38 & 6.0 & 12.0 \\
\hline 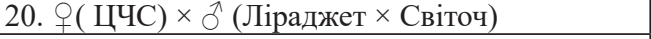 & 1.70 & -4.20 & -3.12 & 0.5 & 12.0 \\
\hline 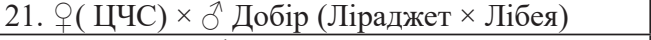 & 5.10 & 0.15 & 0.28 & 2.0 & 12.0 \\
\hline 22. . $($ ЦЧС $) \times \bigcirc($ Вотан $\times$ Livins $)$ & 9.10 & 2.90 & 4.28 & $\mathbf{0 . 0}$ & 2.4 \\
\hline 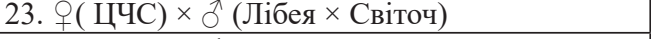 & 1.70 & -4.15 & -3.12 & 1.5 & 0.0 \\
\hline 24. $9($ ЦЧС) $\times$ Оे (Чорний велетень $\times$ Отаман) & 1.10 & -6.00 & -3.72 & 4.0 & 12.0 \\
\hline 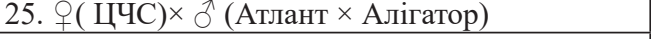 & 3.00 & -2.55 & -1.82 & 1.5 & 12.0 \\
\hline HIP05 & 0.10 & & & 2.78 & 5.14 \\
\hline
\end{tabular}


Урожайність та якісні показники олії гібридів озимого ріпаку $\left(\mathrm{F}_{1}\right)$ на основі цитоплазматичної чоловічої стерильності (2017 р.)

\begin{tabular}{|c|c|c|c|c|c|}
\hline Назва & 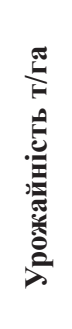 & 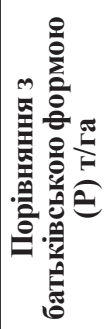 & 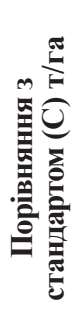 & 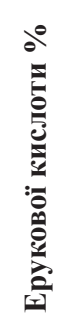 & 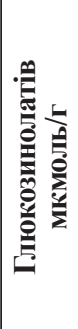 \\
\hline St Чорний велетень & 4.78 & - & - & 0.0 & 2.4 \\
\hline 26. (ЦЧС) / (Світоч / Отаман) & 4.94 & 0.24 & 0.16 & 0.1 & 2.4 \\
\hline 27. (ЦЧС) / (Дар ланів / Livins) & 6.26 & 0.05 & 1.48 & 4.1 & 9.6 \\
\hline 28. (ЦЧС) / (Форте / Барос) & 4.55 & 0.32 & -0.23 & 4.0 & 4.8 \\
\hline 29. (ЦЧС) / (Форте / Чорний велетень) & 5.11 & 1.34 & 0.33 & 0.1 & 12.0 \\
\hline 30. (ЦЧС) / (Ліраджет / Дар ланів) & 5.23 & 0.12 & 0.45 & 0.4 & 4.8 \\
\hline 31. (ЦЧС) / (Вікінг/Алігатор) & 5.83 & 0.18 & 1.05 & 2.1 & 4.8 \\
\hline 32. (ЦЧС) / (Дар ланів / Чорний велетень) & 4.22 & 0.42 & -0.56 & 3.6 & 4.8 \\
\hline 33. (ЦЧС) / (Лібея / Livins) & 3.77 & -0.11 & -1.01 & 3.5 & 4.8 \\
\hline 34. (ЦЧС) / [(Діана / Світоч) / Б / Діана] & 5.21 & 0.18 & 0.43 & 0.0 & 2.4 \\
\hline 35. (ЦЧС) / (Вінер /Алігатор) & 3.63 & 0.30 & -1.15 & 13.0 & 2.4 \\
\hline 36.(ЦЧС) / [(Лібея / Світоч) / (Горизонт / л184)] & 5.87 & 1.01 & 1.09 & 6.6 & 9.6 \\
\hline 37. (ЦЧС) / (Вікінг/Алігатор/Вісбі) & 6.97 & 1.64 & 2.19 & 3.3 & 4.8 \\
\hline 38. (ЦЧС) / [(Чорний велетень / Горизонт) / Данте] & 6.85 & 1.51 & 2.07 & 0.0 & 9.6 \\
\hline 39. (ЦЧС) / (Нельсон / Горизонт) & 6.76 & 1.66 & 1.98 & 0.1 & 0.6 \\
\hline 40. (ЦЧС) / (ПР45Д03 / Горизонт) & 5.11 & 0.78 & 0.33 & 1.9 & 9.6 \\
\hline 41. (ЦЧС) / [(Горизонт / л184) / Дар ланів] & 5.67 & 0.56 & 0.89 & 0.2 & 12.0 \\
\hline 42. (ЦЧС) / (Атлант / Горизонт) & 6.43 & 2.34 & 1.65 & 0.0 & 0.0 \\
\hline 43. (ЦЧС) / (Форте / Світоч) & 4.24 & 1.05 & -0.54 & 2.5 & 4.8 \\
\hline 44. (ЦЧС) / [(Атлант / Алігатор) / ПР45Д01] & 4.87 & 0.43 & 0.09 & 6.9 & 12.0 \\
\hline 3. (ЦЧС) / (НПЦ 9800 / Лірад & 6.73 & 2.49 & 1.95 & 0.4 & 12.0 \\
\hline 11. (ЦЧС) / AP & 4.82 & 0.17 & 0.04 & 0.0 & 4.8 \\
\hline 12. (ЦЧС) / (Вотан / Livins) & 6.11 & 0.99 & 1.33 & 0.4 & 9.6 \\
\hline 13. (ЦЧС) (Livins / Барос) & 6.80 & 0.60 & 2.02 & 0.2 & 4.8 \\
\hline 14. (ЦЧС) / Добір Антарія & 6.74 & 1.03 & 1.96 & 0.4 & 2.4 \\
\hline 18. (ЦЧС) / (Ліраджет / Лібея) & 7.06 & 0.56 & 2.28 & 0.4 & 2.4 \\
\hline 22. (ЦЧС) / (Вотан / Livins) & 7.78 & 2.06 & 3.00 & 0.0 & 0.0 \\
\hline HIP05 & 0.09 & & & 2.25 & 4.96 \\
\hline
\end{tabular}




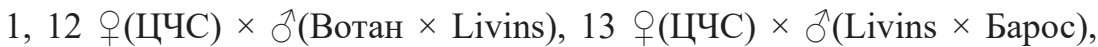

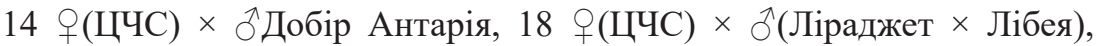
22 +(ЦЧС) $\times \widehat{\jmath}($ Вотан $\times$ Livins). Результати представлені в таблиці 5.

За результатами дворічного випробування ми маємо такі результати: - 2016 рік загальна середня урожайність 7 кращих гібридів склала 7.41 т/га, що на 2.59 т/га перевищило стандарт; - 2017 році ці комбінації показали загальну середню урожайність $6.58 \mathrm{t} /$ га, що на 1.80 т/га вище стандарту. Прояв гетерозису у гібридів ріпаку озимого в середньому за два роки спостерігався нарівні $46 \%$. Основною відмінною особливістю гібридів $F_{1} \in$ прояв ефекту гетерозису за окремими кількісними та якісними ознаками, що зумовлюється гетерозиготним станом організму. Численні дослідження показали перевагу гібридів $\mathrm{F}_{1}$ над сортами, тому сьогодні створення гетерозисних гібридів $\epsilon$ пріоритетним для ріпаку озимого.

\section{4. Висновки}

Доцільно проводити добір за показниками біохімічного складу насіння починаючи 3 гібридів першого покоління, що дає можливість в подальшому виключенні із селекційної програми робіт з покращення біохімічних показників одержаного вихідного матеріалу.

Одержані гібриди ріпаку озимого на основі цитоплазматичної чоловічої стерильності мали прояв гетерозису до сорту стандарту в діапазоні 63-89\%, що є перспективним показником в селекції на гетерозис.

\section{Список літератури:}

1. Осик Н.С. Компонентный состав глюкозинолатов в семенах сортов рапса и сурепицы селекции ВНИИМК. Науч.-техн. бюл. ВНИИМК. Краснодар, 1987. Вып. 1(96). С. 27-29.

2. Snowdon R., Wittkop B. Public-private interaction for research related to oilseed rape breeding in Germany. Australian Research Assembly on Brassicas (ARAB). August, 2011. Pp. 24-32.

3. Пилюк Я.Э. Рапс в Беларуси. Минск : Бизнесофсет, 2007. 239 с.

4. Ghasemi-Golezani K., Shekihzadeh-Mosaddegh P. (2011) Development of Seed Physiological Quality in Winter Oilseed Rape (Brassica napus L.) Cultivars. Not Bot Hort Agrobot Cluj. No. 39(1). Pp. 208-212.

5. Жидкова Е.Н., Карпачев В.В., Никоноренков В.А. Исходный материал для селекции рапса. Кормопроизводство. 1997. № 4. С. 12-14.

6. Технические культуры: селекция, технология, переработка. Сб. науч. тр. М. : Агропромиздат, 1991. 272 с. 
7. Гайдаш В.Д. Ріпак : Монографія. Ужгород : Сіверсія, 1998. 374 с.

8. Song, K. and T.C. Osborn (1992) Polyphyletic origins of Brassica napus: new evidence based on organelle and nuclear RFLP analyses. Genome. No. 35. Pp. 992-1001.

9. Jack Brown, Jim B. Davis, Mary Lauver and Don (2008) U.S. Canola Association Canola Growers Manual. Wysocki - University of Idaho \& Oregon State University. Vol. July. Pp. 71.

10. Journal of Agricultural Sciences (2014) Cytoplasmic male sterility and inter and intra subgenomic heterosis studies in Brassica species. AREVIEW. Vol. 59. No. 3. Pp. 207-226.

11. Australian Government Office of Gene Technology visit. (2008) The Biology of Brassica napus L. (canola). (electronic journal). Version 2: vol. February, pp. 59. Retrieved from: http://www.ogtr.gov.au/internet/ogtr/publishing.nsf/content/canola

12. Azizinia S. (2012) Combining Ability Analysis of Yield Component Parameters in Winter Rapeseed Genotypes (Brassica napus L.) (electronic journal). Journal of Agricultural Science. Vol. 4. No. 4. Pp. 51-59.

13. Schuler T. j., Hutcheson D. S., and. Downey R. K. (1992) Heterosis m intervarietal hybrids of summer turnip rape in western Canada. (electronic journal). Canadian. Journal. of Plant Science. Vol. Jan. Pp.127-136. Retrieved from: www.nrcresearchpress.com.by

14. Литун П.П., Кириченко В.В., Бондаренко Л.В. Гетерозис по признакам с системным контролем у растений и его прогнозирование. Харьков : Тр. по фунд. и пр. генетике (к 100-летнему юбилею генетики). Штрих, 2001. С. 151-169.

15. Івко Ю.О. Ефект гетерозису у гібридів $\mathrm{F}_{1}$ ріпаку озимого. Вісник. Сумський. наи. аграр. ун-ту. Серія «Агрономія і біологія». 2010. Вип. 10. С. 125-129.

16. Лисняк А.Д., Першин А.Ф., Иванов М.В. Особенности ЦМС у гибридов озимого рапса Украинской селекции. Науково-технічний бюлетень Інституту олійних культур НААН. 2011. № 16. С. 21-26.

17. Першин А.Ф., Лисняк А.Д., Плетень С.В., Иванов М.В. Моногенное Наследование восстановления фертильности у гибридов озимого рапса. Науковотехнічний бюлетень Інституту олійних культур НААН. 2012. № 17. С. 8-15.

18. ВИР. Труды по прикладной ботанике, генетике и селекции. Том 170. СПб., 2012. С. 255.

\section{References:}

1. Osik N.S. (1987) Komponentnyy sostav glyukozinolatov v semenakh sortov rapsa i surepitsy selektsii VNIIMK [Component composition of glucosinolates in canola seed varieties and breeding colza VNIIMK]. Nauch.-tekhn. byul. VNIIMK. Krasnodar, vol. 1, no. 96, pp. 27-29.

2. Snowdon R., Wittkop B. (2011) Public-private interaction for research related to oilseed rape breeding in Germany. Australian Research Assembly on Brassicas (ARAB). August, p. 24-32.

3. Pilyuk Ya.E. (2007) Raps v Belarusi [Rapeseed in Belarus]. Minsk: Biznesofset, p. 239. 
4. Ghasemi-Golezani K. Shekihzadeh-Mosaddegh P. (2011) Development of Seed Physiological Quality in Winter Oilseed Rape (Brassica napus L.) Cultivars. Not Bot Hort Agrobot Cluj, no. 39(1), pp. 208-212.

5. Zhidkova E.H., Karpachev V.V., Nikonorenkov V.A. (1997) Iskhodnyy material dlya selektsii rapsa. Kormoproizvodstvo, no. 4, pp. 12-14.

6. Tekhnicheskie kul'tury (1991): selektsiya, tekhnologiya, pererabotka Sb. [Industrial crops: selection, technology, processing Sat]. nauch. tr. M.: Agroproizdat, p. 272.

7. Ghajdash V.D. (1998) Ripak: Monoghrafija [Rapeseed: Monograph]. Uzhghorod: Siversija, p. 374.

8. Song, K. and T.C. Osborn (1992) Polyphyletic origins of Brassica napus: new evidence based on organelle and nuclear RFLP analyses. Genome, no. 35, pp. 992-1001.

9. Jack Brown, Jim B. Davis, Mary Lauver and Don (2008) U.S. Canola Association Canola Growers Manual. Wysocki - University of Idaho \& Oregon State University, vol. July, p. 71.

10. Journal of Agricultural Sciences (2014) Cytoplasmic male sterility and inter and intra subgenomic heterosis studies in Brassica species. A REVIEW, vol. 59, no. 3, pp. 207-226.

11. Australian Government Office of Gene Technology visit. (2008) The Biology of Brassica napus L. (canola) (electronic journal). Version 2: vol. February, pp. 59. Retrieved from: http://www.ogtr.gov.au/internet/ogtr/publishing.nsf/content/canola

12. Azizinia S. (2012) Combining Ability Analysis of Yield Component Parameters in Winter Rapeseed Genotypes (Brassica napus L.) (electronic journal). Journal of Agricultural Science, vol. 4, no. 4, pp. 51-59.

13. Schuler T. j., Hutcheson D. S., and. Downey R. K. (1992) Heterosis m intervarietal hybrids of summer turnip rape in western Canada (electronic journal). Canadian. Journal. of Plant Science, vol. Jan, pp. 127-136. Retrieved from: www.nrcresearchpress.com by

14. Litun P.P., Kirichenko V.V., Bondarenko L.V. (2001) Geterozis po priznakam $\mathrm{s}$ sistemnym kontrolem u rasteniy i ego prognozirovanie [Heterosis by traits with systemic control in plants and its prediction]. Khar'kov: Tr. po fund. i pr. genetike (k 100-letnemu yubileyu genetiki). Shtrikh, pp. 151-169.

15. Ivko Ju.O. (2010) Efekt gheterozysu u ghibrydiv $F_{1}$ ripaku ozymogho [The effect of heterosis in $\mathrm{F}_{1}$ hybrids of winter rape]. Visnyk Sumsjkyj. nac. aghrar. un-tu. Serija «Aghronomija i biologhija», vol. 10, pp. 125-129.

16. Lisnyak A.D., Pershin A.F., Ivanov M.V. (2011) Osobennosti TsMS u gibridov ozimogo rapsa Ukrainskoy selektsii [Features of CMS in winter rape hybrids of Ukrainian selection]. Naukovo-tekhnichniy byuleten' Institutu oliynikh kul'tur NAAN, no. 16, pp. 21-26.

17. Pershin A.F., Lisnyak A.D., Pleten' S.V., Ivanov M.V. (2012) Monogennoe Nasledovanie vosstanovleniya fertil'nosti u gibridov ozimogo rapsa [Monogenic Inheritance of Fertility Restoration in Winter Rape Hybrids]. Naukovo-tekhnichniy byuleten' Institutu oliynikh kul'tur NAAN, no. 17, pp. 8-15.

18. VIR (2012) Trudy po prikladnoy botanike, genetike i selektsii. SPb., vol. 170 , p. 255. 